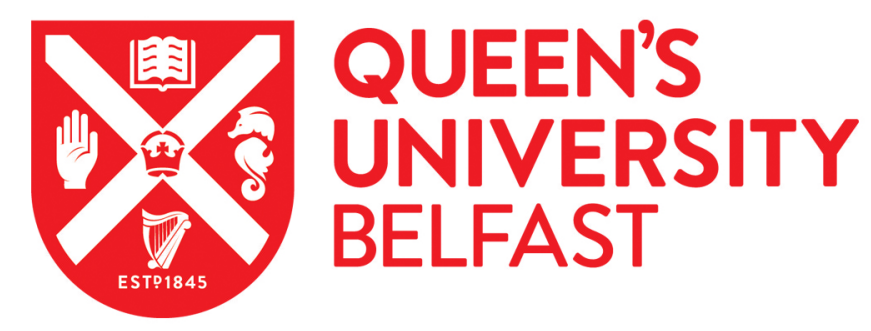

\title{
'Letting the right one in': provider contexts for recruitment to initial teacher education in the United Kingdom
}

Davies, P., Connolly, M., Nelson, J., Hulme, M., Kirkman, J., \& Greenway, C. (2016). 'Letting the right one in': provider contexts for recruitment to initial teacher education in the United Kingdom. Teaching and Teacher Education, 60, 291-302. https://doi.org/10.1016/j.tate.2016.09.003

\section{Published in:}

Teaching and Teacher Education

\section{Document Version:}

Peer reviewed version

Queen's University Belfast - Research Portal:

Link to publication record in Queen's University Belfast Research Portal

\section{Publisher rights}

Copyright 2016 Elsevier.

This manuscript is distributed under a Creative Commons Attribution-NonCommercial-NoDerivs License

(https://creativecommons.org/licenses/by-nc-nd/4.0/), which permits distribution and reproduction for non-commercial purposes, provided the author and source are cited.

\section{General rights}

Copyright for the publications made accessible via the Queen's University Belfast Research Portal is retained by the author(s) and / or other copyright owners and it is a condition of accessing these publications that users recognise and abide by the legal requirements associated with these rights.

Take down policy

The Research Portal is Queen's institutional repository that provides access to Queen's research output. Every effort has been made to ensure that content in the Research Portal does not infringe any person's rights, or applicable UK laws. If you discover content in the Research Portal that you believe breaches copyright or violates any law, please contact openaccess@qub.ac.uk. 


\title{
'Letting the right one in': provider contexts for recruitment to initial teacher education in the United Kingdom
}

\section{Peter Davies ${ }^{1}$, Mark Connolly ${ }^{2}$, James Nelson ${ }^{4}$, Moira Hulme ${ }^{3}$, John Kirkman ${ }^{1}$, and Celia Greenway ${ }^{1}$}

${ }^{1}$ School of Education, University of Birmingham, ${ }^{2}$ School of Social Science, Cardiff University, ${ }^{3}$ School of Education, Manchester Metropolitan University, ${ }^{4}$ School of Education, Queens University Belfast.

\begin{abstract}
We exploit policy differences within the UK to investigate provider context and recruitment to initial teacher education (ITE). We identify three dimensions of variation: conceptions of professionalism, universal or context specific preparation and costs and benefits to providers. University-led ITE programmes used similar criteria and processes in each jurisdiction, but there were differences between university-led and school-led recruitment. Our study suggests that the current shortfall in recruitment to ITE in England may be a product of the contextual constraints which schools experience. It also suggests that school-led recruitment may tend to emphasise short-term and school-specific needs.
\end{abstract}

\section{Key words}

Entry to teaching; Adverse selection; Professionalism and craft conceptions of teaching; 'Home international' comparison; Teacher quality; alternative routes into teaching

\section{Highlights}

- A model of relationships between context and providers' recruitment to ITE

- HE recruitment criteria and processes similar in $4 \mathrm{UK}$ jurisdictions

- School-led recruitment to ITE emphasising 'classroom readiness' and school needs

- Costs and benefits to providers the main source of difference in recruitment 


\section{Introduction}

Since individual teacher quality is central to school improvement (McKinsey, 2007; Kane, Taylor, Tyler \& Wooten, 2011; Slater, Davies \& Burgess, 2012), the recruitment of new teachers is critical to the achievement of policy objectives on 'raising standards'. Policymakers may respond to this imperative through measures they believe will improve the quality of new recruits to teaching, encourage 'failing' teachers to leave the profession, provide incentives to direct teachers' effort and focus, or provide professional development to raise teachers' capability. We focus on the first of these strategies and, in particular, on the recruitment of entrants to teaching.

Despite its policy salience, a review of research on teacher recruitment (Allen, 2005) for the Education Commission for the States in the US concluded that there had been no adequate studies of what makes a difference in the recruitment of new teachers. Whilst subsequent studies have added to knowledge, we judge that there is a place for fundamental research which maps out differences between recruitment processes in initial teacher education (ITE) which may be related to the context in which ITE is provided. To this end, we draw on interviews with Higher Education Institution (HEI) and school providers in each of the four jurisdictions within the UK to suggest a way of framing the problem which draws upon theory in social science. In recent years, the four jurisdictions within the UK have adopted sharply different policies towards recruitment to initial teacher education. However, trends in labour market conditions are similar throughout the UK. This encourages the view that differences within the UK in recruitment to ITE are attributable to policies. Therefore, analysis of variation in the UK offers the prospect of insights into relationships between policies, practice and recruitment outcomes that will be of international relevance.

In the next section we summarise policy differences within the four jurisdictions (England, Northern Ireland, Scotland and Wales) and explain why a comparison of practice between these jurisdictions offers a fruitful way of understanding relationships between context and recruitment to ITE. We review existing evidence of recruitment practice in teacher education in the light of theoretical perspectives drawn from economics and sociology. We continue with a description and justification of our method, followed by our results and conclusions.

\section{The contexts for recruitment to teaching in the UK: policies and outcomes}

In this section we aim to demonstrate the policy salience of this study and establish a rationale for comparing recruitment practice in different parts of the UK. General labour market conditions are routinely recognised as affecting the quantity and quality of applicants to teacher training (Schalock, 1979; Applegate, 1987; Eide, Goldhaber \& Brewer, 2004; Guarino, Santibanez \& Daley, 2006). The gradual improvement in employment prospects for new graduates in the UK since the financial crash is shown in Table 1 (see also CIPD 2014). Given these data we might expect a slight increase in difficulty in recruiting to ITE in the UK over this period.

\section{Table 1 about here}

The UK is conventionally regarded as a single labour market and there is a long history of graduate labour mobility (not least for new teachers) between the four jurisdictions. Moreover, the percentage of first time degree graduates unemployed 6 months after graduation did not vary between the four jurisdictions during this period (HESA, 2015). Therefore, by comparing recruitment to ITE we aim to examine differences in perspectives and practice through a 'home internationals' comparison 
(Brisard, Menter, \& Smith, 2007; Author, 2015) whilst controlling for general labour market conditions.

In England, the ratio of actual recruits to target levels for recruitment to ITE fell steadily after 2010 (Figure 1). Public concern about implications for schools and students has also noted even greater shortfalls in recruitment to ITE in some secondary subjects, including those prioritised by government (Husbands, 2015; National Audit Office, 2016). The trend in England contrasts with the other parts of the UK where recruitment to target fluctuated close to $100 \%$. Although recruitment in Scotland followed a similar pattern to England between 2010 and 2013, the symmetry has disappeared in the past two years. Recruitment to ITE for secondary education in Wales has also become more difficult in the last two years. This comparison suggests that it is difficult to attribute changes in recruitment to ITE entirely to labour market fluctuations.

\section{Figure 1 about here}

The size of the school sectors in each jurisdiction might have some bearing on fluctuations in recruitment. In 2015/16, the total numbers of places on pre-service teacher education programmes in each jurisdiction were: England 43,516, Northern Ireland 580, Scotland 3,437, and Wales 1,630 (sources as per Figure 1). However, the annual target for new teachers in England varied very little (between 1 and 3\%) from year to year. Annual change in targets fluctuated by a bigger proportion in other jurisdictions (notably Scotland). Moreover, it is the distinctive trend in the rate of recruitment in England which is our interest in this paper.

Therefore, the comparison in Figure 1 encourages us to consider possible effects of differences in teacher recruitment policies in the four jurisdictions. Despite the devolution of administrative responsibility for education to the Scottish Office in 1885, teacher education was provided through HEIs in each of the countries in the UK throughout the bulk of the last century. Successful completion of 'initial teacher education' (ITE) was marked by the award of a 'Bachelor of education' degree or, for those who had already completed an undergraduate degree in a specific subject, a 'Postgraduate certificate of education'. Successful completion of HEI-led ITE led automatically to 'qualified teacher status' for state schools, awarded by government on the basis of its quality assurance inspection of providers. More recent devolution of education policy to Northern Ireland and Wales means that there has been scope for each jurisdiction to develop distinctive approach to the recruitment of new teachers. However, it is England rather than the other jurisdictions which has moved away from the traditional model of HEI-led ITE. We summarise the emerging differences in four related themes.

First, whilst the other jurisdictions have used the term 'profession' to express their view of teaching, the government in England has turned to the term 'craft'. One Minister of Education, (Gove, 2010) declared that "teaching is a craft and it is best learnt as an apprentice observing a master craftsman or woman". In contrast, politicians in Northern Ireland, Scotland and Wales have commissioned leading academics from other nations to review their provision of teacher education. Reviews of ITE commissioned by the Welsh Government, (Tabberer, 2013; Furlong, 2015) emphasised the importance of providing a strong research context for preparation for teaching. An influential review for the Scottish Government (Donaldson, 2011) explicitly eschewed the term 'craft' whilst advocating a conception of ITE as professional preparation requiring (p. 42) 'exploration of theory through practice'. A similar view of professionalism has been at the foundation of the partnership-based approach to teacher education in Northern Ireland since 1996 (DENI, 2010).

Second, policy makers have adopted sharply different positions on which organisations should take the lead in ITE. Even in 2006 McKinsey described the ITE system in England as the most diverse in the world. 'TeachFirst' was introduced in England in 2002 to recruit and train high achieving graduates to teach in schools serving disadvantaged neighbourhoods. Following principles 
established in the 'Teach for America' programme (Ellis et al., 2016), participants were offered the incentive of a guaranteed a job in a 'blue-chip' company after a minimum of two years in teaching. However, the dominant change in England has been a shift towards schools taking the lead responsibility for recruitment and training. The Department for Education in England (2011) set out what it described as an agenda for reform of initial teacher training which asserted that schools should take a stronger role in the recruitment process. This 'School Direct' route was introduced in 2012/13 and positioned schools as lead providers with the determining voice in recruitment. By 2014/15 School Direct was responsible for roughly 30\% of all ITE recruitment. One consequence has been that between 2011/12 and 2015/16 the number of HEI providers fell from 74 to 68 and the number of school consortia providing ITE rose from 107 to 150. Targets for recruitment to ITE in England had anticipated that schools would not fill all ITE places allocated to them. In 2012/13 total allocations had been $12 \%$ greater than target and in 2013/14 this was increased to $17 \%$. However, the School Teachers' Review Body (Rice 2015, p.9) noted that only 61\% of ITE places allocated to School Direct had been taken up. This shortfall was greater than expected. The Welsh Government (Lewis, 2013) endorsed the Tabberer Review's advocacy of specialist 'training schools', whilst indicating a willingness to expand school-based teacher training if proposed changes in provision led by Higher Education Institutions (HEIs) did not improve the quality of new teachers while also sanctioning a pilot of the school-based Teach First progamme The Donaldson Review in Scotland advocated a strengthening, rather than a weakening, of the role of HEIs in ITE on the grounds of providing new teachers with a strong intellectual challenge. The most recent review of ITE in Northern Ireland (Sahlberg, Broadfoot, Coolahan, Furlong \& Kirk, 2014) did not recommend any fundamental change in the role of HEIs, saying only that the campus and school based strands of ITE should be "carefully coordinated to create a coherent educational experience" (p. 31).

Third, there have been differences between the jurisdictions in the role of government in quality assurance and improvement. General Teaching Councils (GTCs) with professional representation were established in each of the four jurisdictions: Scotland (1965); Northern Ireland 1998; England (2000); and Wales 2006 (EWC). However, the GTC for England was abolished in 2012 and the GTC in Northern Ireland and EWC in Wales (reconfigured in 2015 as the Education Workforce Council) have more limited roles than the GTC in Scotland which, in 2012, was granted independence from government. Nonetheless, governments in each jurisdiction exercise power over recruitment to ITE through inspecting providers and allocating places. Nonetheless, policymakers in England have increasingly entrusted quality enhancement (in recruitment as well as in course design) to competition between many diverse providers and applicants' ability to distinguish between better and worse providers. In contrast, policymakers in Wales have aimed to manage quality through consolidating provision in a smaller number of providers (Furlong, 2006). Northern Ireland and Scotland have maintained quality enhancement systems that rely on relationships between HEIs and government bodies (in Scotland, local authorities have worked with HEIs in a planning approach to teacher recruitment). These differences may reflect the size of each jurisdiction as well as government beliefs about the proper role of government in the labour market.

Fourth, England has placed much more emphasis on the value of recruiting new teachers with stronger academic credentials. Bachelor degrees throughout the UK are classified with the grades 1 (highest), 2i, 2ii, 3 or pass degree. Recruitment policy in England (e.g. Department for Education, 2011) has aimed to increase the proportion of entrants to teaching with degree classifications of $2 \mathrm{i}$ or above. Wales has followed England's example in providing financial incentives for applicants to ITE from graduates with high degree classifications in shortage subjects, whilst placing less emphasis on the importance of degree classification in judging recruitment to teaching as a whole (Tabberer, 2013). In contrast, the Donaldson Report (2011) in Scotland and Sahlberg et al. (2014) in Northern Ireland made no comment on degree classifications. Donaldson was more concerned with the relevance of degree content to the school curriculum, whilst Sahlberg et al. (2014) emphasised academic provision within ITE which would increase 'research literacy' and prepare for Masters' level study. 
This brief summary of recruitment patterns and policies raises the possibility that differences between the four jurisdictions in terms of who recruits to ITE (provider context) may be partially responsible for differences in rates of recruitment and may also be associated with differences between the characteristics of recruits. This motivates our qualitative investigation of recruitment processes used by different providers in each of the four jurisdictions. We now turn to the question of why the provider context for recruitment to ITE might affect the quantity and attributes of recruits.

\section{Recruitment to ITE: the role of provider context}

In this section we present a frame in which to interpret our evidence. This section was developed in two stages. Before we undertook the research we conducted a search of literature which explicitly referred to recruitment in the context of routes into teaching. This yielded a fairly small number of studies which tended not to offer a theorisation of the role of the context in which ITE was provided. Once we had gathered our data we conducted a further review of literature pursuing themes which were suggested in the interviews. On this basis we suggest that the context in which ITE is provided may affect recruitment decisions either through beliefs about the desired characteristics of new teachers (at the end of ITE) or anticipated costs and benefits to the provider of accepting an applicant. This section considers each of these possibilities, referring to relevant ideas from economic and sociological analysis of recruitment to professions and the rather small literature on recruitment to teaching in different contexts.

\section{1 Desired characteristics of new teachers}

The context of provision of ITE might affect beliefs about the desirable characteristics of new teachers: through providers' beliefs about whether teaching is a 'profession' and whether provision is regarded as a preparation for all or a particular type of school.

\subsubsection{Profession or craft?}

Characteristics of traditional, 'occupational professionalism' have been identified by social scientists drawing on different traditions (see for example Matthews, 1991; Freidson, 2001; Gorman \& Sandefur, 2011). Two of these characteristics are most relevant to selection of applicants to ITE: (i) complex relationships between knowledge and actions which are not easily reducible to transferable rules; and (ii) technical autonomy in the conduct of work. The assertion that teaching is a craft concentrates on denying the first of these characteristics. The second characteristic has been threatened from a different direction. Power and employment relationships in public services in England have been steadily transformed by the emergence of 'new public management' (Brignall \& Modell 2000). Professional judgement and autonomy have been limited in favour of evaluation of employee performance relative to external standards (a process referred to by Ball, 2003 as performativity). according to Evetts (2009), this has produced a new form of 'organisational professionalism'. This is distinguished from 'occupational professionalism' principally by the replacement of 'technical autonomy' with organisational monitoring and evaluation of professionals' work against external standards. Evidence from comparison of teaching with other occupations (Rowan, 1994; Ingersoll \& Merill, 2011), and analysis of teaching tasks (e.g. Doyle, 2006) have left room for debate about the extent to which teaching is best understood as an 'occupational profession' (Author, 2010a; Pring \& Pollard 2011). We now consider some implications for recruitment to ITE of the assertion (Gilroy, 1993; Barton, Bartlett, Whitty, Miles \& Furlong, 1994; Edwards, Gilroy \& Hartley, 2002) that HEIs, but not schools, regard teaching as an 'occupational profession'

First, HEIs would believe they face a substantial 'adverse selection' problem (Akerlof, 1970) when recruiting to ITE. That is, they will want to select individuals who will abide by professional ethics such that, even when they are not observable and regardless of how they are rewarded, they will use their knowledge and effort in the best interests of pupils (Sinclair \& Picogna, 1974; Schalock, 1979; 
Kay-Cheng \& Wah Kam, 1990; Roberts \& Dietrich, 1999; Delfgaauw \& Dur, 2008; Georgellis, Iossa \& Tabvuma, 2010; Uusiautti \& Määttä, 2013). However, since teaching is largely in the state sector it is also likely to be relatively attractive to individuals seeking job security (Lewis \& Frank, 2002) and this will be an issue for all ITE providers. Therefore, we might expect HEIs to place more emphasis than schools on detecting intrinsic attitudes which will drive commitment towards pupils' needs. Second, HEIs would place more emphasis than schools on recruiting individuals who display a commitment to education as a vehicle for improving society (Knight et al., 1994; Jacobwitz, 1994; Johnson \& Reiman, 2007; Bullough, 2011; Evans, 2011). Hoyle (1974) identified this as an element within what he categorised as extended professionalism. Schools might place more emphasis on applicants' readiness to fit in with a school's culture or brand (in line with the predictions of 'organisational professionalism'). Third, if schools believe that teaching is a craft they are less likely than HEI tutors to believe that knowledge for teaching is complex and contingent (Buehl \& Fives, 2016) and will have more confidence that applicants' suitability can be readily judged relative to known attributes of a 'good teacher'. By contrast, HEIs would be expected to place more weight on trying to judge applicants' capacity for learning how to act responsively in different circumstances (Musset, 2010).

\subsubsection{Universal or context specific preparation}

Recruitment to ITE may attempt to select applicants to meet the needs of a wide range of schools or to select applicants who will fit in well at a particular type of school. The distinction between general and specific human capital provides one way of analysing this difference (Ost, 2009; Xu, Ozek \& Corritore, 2012; Jackson, 2013). General human capital refers to a development in capacities for employment in any occupation (as in the assertion that TeachFirst develops capacities which will be valuable in blue-chip companies). Conversely, the benefits of human capital development may be specific either to an occupation (teaching), an organisation (a group of schools or an individual school) or a task (such as teaching a particular age group in a secondary school or a for a particular examination specification in a secondary school). Preparation of teachers to suit the needs of a particular group of schools has become salient in England through the development of 'academy chains'. These schools are funded direct from central government and managed as a group by a Trust board. Some of these academy chains have sought to establish a distinctive brand through a common approach to teaching and teacher recruitment (Chapman, 2013). The case for preparing all new teachers for linguistically and culturally diverse societies (Smyth 2013) presumes an occupational rather than organisational scope for human capital development.

Another strand of literature has suggested that applicants to ITE will be more effective if they teach in schools which are well matched to their prior characteristics: in terms of race (Villegas \& Davis, 2007; Dee, 2005, 2007), socio-economic background (Haberman, 1995; Sleeter, 2001) or academic credentials (Clotfelter, Glennie, Ladd and Vigdor. 2006). This 'teacher matching' literature also provides some evidence for benefits of matching teachers and students by sex (Dee, 2005, 2007). However, these studies generate tensions for policy and practice in the face of the role of schools in challenging inequalities, parental suspicions of male primary teachers and racism (Carrington \& Skelton, 2003). Moreover a study of primary age children in England (Carrington, Tymms \& Merrell, 2008) found no association between the sex of teachers and children.

The literature on preparing teachers in pluralistic societies (e.g. Bryk, Lee \& Holland, 1993; McLaughlin, 2003; Author, 2010b) combines both strands. Once it is accepted that different communities within a society should expect children to be educated in ways that nurture those communities it makes sense for providers to specialise in recruiting individuals who are well matched to those communities and who will respond positively to ITE which is tailored to the needs of those communities.

The limited references to teacher-context matching in the literature on HEI-led recruitment to ITE (e.g. Moran, 2008; Thomson et al., 2011) have suggested a broad commitment to matching by innate characteristics (race and socio-economic background), but with limited success. In contrast, analysis 
of recruitment to 'alternative' routes into teaching in the US (e.g. Stoddart, 1990) have reported relatively high proportions of recruits from minority ethnic groups and targeting the needs of urban schools. This implies that providers who are concerned about the needs of schools serving particular communities will have a stronger imperative to recruit entrants to ITE with backgrounds that match those communities (in contrast to HEIs which serve large and disparate regional or national communities.) Nonetheless, TeachFirst which recruits for schools in socially disadvantaged areas does not use socioeconomic background as a criterion in its selection.

\subsection{Costs and benefits of training}

Recruitment to ITE programmes may also be viewed as an investment decision by the provider: a decision in which they will weigh the likely costs and benefits they will incur if they accept an applicant. A small US literature (e.g. Levin \& Quinn, 2003; Stotko, Ingram, \& Beaty-O'Ferrall, 2007) has questioned the responsiveness to benefits and costs of local bureaucracies when recruiting new teachers in urban localities. This echoes the more general public choice critique (Buchanan \& Tullock, 1962) which suggested that public service employees would tend towards 'safety first' procedures to foster their career prospects in an organisation which is largely insulated from the voices and choices of consumers. Larger and more bureaucratic providers might be less responsive to incentives.

Providers will expect to incur greater costs if they accept applicants they regard as more risky since these recruits would require greater support to reach required standards by the end of the course. In an HE-led programme these costs will be shared between the HEI and practice schools whilst in a school-led programme the costs will be borne largely by the school. Moreover, schools will also bear additional costs from effects on children of poor teaching by weak recruits. Roughly one half of primary schools and one third of secondary schools responding to a survey in England in 2014 reported this as the second highest concern about taking responsibility for ITE (Allen, Belfield, Greaves, Sharp \& Walker, 2014). Therefore, we might expect the costs of recruiting a weak applicant to be weighted more heavily when schools rather than HEIs are leading recruitment. The benefits to the provider may come in several forms: income from fees; reputational effects; and easing future recruitment problems. Fee income is likely to be more important to providers when it is required to sustain core activity (such that there is limited capacity to reduce staffing costs if there is a shortfall in recruitment). This is more likely to be the case for HEI providers. Schools, rather than HEIs may ease their future recruitment of teachers through recruiting applicants who will become very good teachers.

These costs and benefits are subject to considerable uncertainty at the point of recruitment to ITE. For example, academic qualifications have been frequently reported as the main criteria for selection of applicants (e.g. Schalock, 1979; Kay-Cheng \& Wah Kam, 1990; Moran, 2008). However, graduate trainees' degree performance is weakly related to performance in ITE (Caskey, Peterson \& Temple, 2001; Casey \& Childs, 2007; Heinz, 2013) and studies of teacher value-added in the UK (e.g. Slater et al., 2011) and the US (e.g. Pil \& Leana, 2009; Atteberry, Loeb \& Wyckoff, 2015) have not found an association between teachers' academic qualifications and their value-added. Moreover, interviews of applicants (which commonly form a part of the selection process) have, in other fields, been found to be weak predictors of subsequent success (Wise, 1987, 1997). Finally, new teachers improve at substantially different rates during the early years of teaching (Goldhaber, Grout \& HuntingtonKlein, 2014; Atteberry et al., 2015). School providers which bear a greater portion of the costs of weak recruits and a greater portion of the benefits (if they subsequently employ trainees) face stronger incentives than HEIs to be cautious in the face of the uncertainty in predicting the trajectories of recruits to ITE.

\subsection{Summary}

Policymakers have justified the differences that have emerged between England and the rest of the UK on the basis of their beliefs about the validity of describing teaching as a profession or a craft. 
Whether this matters for recruitment to ITE depends largely on whether recruitment decisions in HEIs and schools reflect different conceptions of teaching either in terms of 'profession or craft' or different conceptions of 'teaching as a profession'. Whilst 'matching teachers to students' has been a prominent theme in debate over routes into teaching in the US, it has rarely been cited in the policy literature in the UK. The distinction between general and specific human capital and the implications for providers of factors affecting the benefits and costs of recruiting to ITE have also received little attention in the UK policy literature and our research examines whether these factors might matter a great deal in practice.

\section{Method}

In this research we examined evidence of relationships between recruitment practice and contexts for recruitment to ITE. Our evidence base comprises in-depth interviews with 29 HEI tutors, 24 teachers and 5 local authority officials responsible for the selection of applicants to ITE and first teaching jobs in England, Northern Ireland, Scotland and Wales. We were interested in two kinds of evidence: (i) recruiters' attributions of relationships between their practice and the circumstances in which they worked; and (ii) patterns of similarity and difference (or 'linkages' in the words of Ritchie, Spencer \& O'Connor, 2003) which were suggested by comparison of transcripts from recruiters working in different contexts. We judged that recruiters' attributions would provide an insufficiently rich picture given that interviewees could be unaware of some contextual influences on their practice. We used triangulation, peer review, member checks and thick description as verification procedures (Creswell, 1998; Anfara, Brown \& Mangione, 2002). For triangulation we interviewed more than one individual from most of the institutions in our sample and requested examples of documentation. Gathering different voices from the same institution proved more illuminating than documents. We used a reference group of senior policy makers and teachers responsible for recruitment in developing our interview schedule and establishing descriptive categories in our analysis. Our research team included academics with different disciplinary backgrounds and different experiences of policy environments and our internal review was supplemented by scrutiny from other academics at authors' institutions. In addition, our analysis of patterns in the data was revised following review from academics beyond the team following presentations and discussions in 2015. The descriptions provided in the transcripts were "thick" in so far as they established interviewees' experience, sense of role and purpose, relationship of role to practice, exemplars of practice and comparison of practice with others.

The sample of interviewees is set out in Table 2. Our interviewees were selected to uncover possible differences within and between jurisdictions. We therefore selected interviewees working at institutions with differing contexts within each jurisdiction (e.g. more and less selective HEIs and schools serving more and less advantaged localities by SES). We also included individuals with different types of responsibility in the recruitment process. Within England we interviewed tutors from six HEIs (three research intensive and three teaching intensive). Our sample of school-led ITE included teachers working in primary and secondary schools which were experienced different levels of difficulty in recruiting to first teaching posts. Our sample from Scotland included 4 Local authority (LA) officers as, following the formal linkage between ITE and teachers' induction year under the McCrone agreement in 2002 (see SEED 2001), they have formal partnerships with HEIs in the preparation of new teachers. In reporting our data we indicate interviewee role, institutional type and jurisdiction.

\section{Table 2 about here}

We drew on discussions with a group of policymakers and senior school managers (two half-day meetings) and our reading of the literature on recruitment to ITE in framing a set of issues to be 
explored through the interviews. We then devised an interview schedule with 'headline' questions and follow up prompts to probe interviewees' reasoning and assumptions (Qu \& Dumay, 2011). In addition, interviewees were asked to bring along any recruitment material (advertisements, criteria etc.) which were used as interview prompts (see Hurworth, 2012). We aimed to reduce the scope for 'social desirability bias' (Engberg, 2004; Gonyea, 2005), through (i) questions (such as 'what criteria do you use in your recruitment?') which avoided any indication of what the interviewer thought might be 'a good criterion'; (ii) questions which avoided signalling issues (such as using applicants' tendency towards critical reflection as a critical decider) which have been suggested in literature as important context related differences in teacher education; and (iii) requests for observations about the recruitment practice of colleagues (since interviewees were less likely to reveal aspects of their own practice which they thought might be considered questionable).

Each interview took place in a location chosen by the interviewees (normally their place of work). Interviews lasted between 30 and 60 minutes and all but one were recorded using a digital recorder. All interviewees were informed about the purpose of the project and assured that any data would be anonymised and treated in confidence and that they would have the right to withdraw at any time (BERA, 2011). The political sensitivity of ITE recruitment was reflected in one interviewee's reluctance to be recorded: this participant was happy to give consent to the interview but did not give permission for audio recording on the grounds that issues around recruitment to ITE were particularly sensitive in the current context of teacher education reform in the jurisdiction where he worked. Permission was granted to the researcher for making hand-written notes during the interview. These were subsequently typed up and used alongside the other transcripts. All of the original recordings were stored locally at each institution on password protected computers. The transcripts of each interview were anonymised and shared with research colleagues via the project's workspace.

We began our analysis by creating codes for the transcripts within each jurisdiction. Following Miles and Huberman (1994) these were descriptive/inferential codes. We agreed on twenty-two descriptive codes (see Appendix A) through on-line dialogue via our workspace, followed by a face to face meeting. A critical factor at this stage was agreeing on descriptors that used language applicable to different policy contexts. Agreement on the individual descriptive codes was facilitated by discussion about more general descriptions (the four headings in Appendix A) which were closely aligned to the sequence in our interview schedule. We explicitly considered whether interviewees' responses suggested different ways of regarding particular aspects of the recruitment process. Once we had agreed our frame we checked consistency in application using our remote workspace. As a first stage in developing pattern codes (Miles \& Huberman, 1994) we examined participants' attributions of contextual influences. These concentrated on section 1 in Appendix 1. Discussion with academic peers encouraged us to reconsider our pattern codes in the light of an extended review of literature (Appendix 2). At both stages we used specific quotations in discussing relationships between pattern codes, descriptive codes and transcripts.

\section{Results}

For the sake of brevity we present our results with brief comments in the light of the previous section. Comparison of accounts suggested some similarities and some differences between recruitment in different contexts with regard to 'teaching as a profession' and 'universal or specific preparation?' Interviewees' direct attributions of contextual effects on their practice concentrated on references to the uncertain costs and benefits of providing ITE. With nearly sixty interviews it is not possible to convey complete pictures of individuals in our sample. Moreover, we do not assume that each interviewee held a coherent and singular perspective on recruitment to ITE. Our purpose was to 
examine similarity and difference in perspectives on recruitment and indications of ways in which these were related to provider contexts.

\subsection{Profession or craft?}

HEI tutors, teachers and LA officers were equally likely to declare the importance of identifying applicants who were passionate about teaching and had a 'strong work ethic'. One HEI tutor (England) believed they could 'see that passion in their eyes'. Another tutor (HEI, teaching intensive, England) referred to the importance they attached to applicants'

understanding of the demands of primary teaching before you commit fully to the course.

and a primary head teacher (England) asserted they were looking primarily for

candidates who say we want to make a difference, ... a passion to actually impacting and steering and shaping young people's lives and primary school teachers

The ubiquity of this kind of comment suggested that whatever the impact of 'new public management' on school environments (particularly in England), recruiters still believed it was important to crucial to distinguish between altruistic and self-interested applicants (the adverse selection problem). They also believed they could overcome this problem through professional judgement.

You need to know that these people are going to be organised and they're going to be resilient and are going to be able to be independent, (Secondary school co-ordinator, School Direct, England)

Recruiters did not refer directly to the complexity of knowledge required for teaching but they did refer to the importance of degree qualifications and capacity of reflection. However, HEI tutors and teachers referred to degree qualifications as indicators of depth and relevance of subject knowledge. In some cases HEI tutors regarded pedagogic knowledge as contingent upon subject knowledge.

It's an indicator of the subject knowledge. It's not necessarily an indicator of pedagogic ability. (HEI teaching intensive tutor, England)

You need to understand subject knowledge in order to understand pedagogy (HEI teaching intensive tutor, NI)

However, our interviewers did not suggest that they viewed degree classification was an indication of general intellectual capacity that would enable recruits to make sense of the complex knowledge demands of teaching. The few references to general academic capability focused on coherent writing (within the course and in school):

And if they can't really actually write at that level does that mean it's very difficult for them to progress in terms of career because they need to write self-evaluation reports, formal reports to the head teacher and so forth. (HEI Tutor, Wales)

Teachers and HEI tutors also gave similar prominence to the importance of identifying which applicants were reflective. However, reflection may take different forms according to (i) beliefs about whether knowledge for teaching is complex and uncertain and (ii) whether teachers are expected to make and justify independent judgements about the quality of their teaching. Readiness to talk of 'reflective practitioners' appeared to mask differences which became more apparent following further probes:

I saw one the other week in a primary school, he came out and why he got it was because he said, 'I did that wrong'. His reflection was immediate. (School Co-ordinator, School Direct, England)

(I am looking for) 'some sense of a scholarly understanding of the role'. (HEI research intensive tutor, England) 
The first comment located reflection in a rapid assessment of an action as 'wrong'. This school coordinator repeated the phrase 'reflection was immediate' when finishing her anecdote. It implies that judgement is fairly straightforward and focuses on teacher actions. The second comment implies a more considered assessment of an approach to teaching which takes the occupation rather than the organisation as its reference point. In our sample we found that HEI tutors in each jurisdiction were more likely than teachers to describe reflection in terms that presumed that knowledge for teaching was complex and uncertain.

\subsection{Universal or specific preparation?}

HEI tutors in each jurisdiction claimed they were preparing new teachers for any school. A minority also referred to ITE recruitment enabling ethnic and social mobility to serve what they regarded as a fair society. However, school co-ordinators frequently (though not universally) spoke of training teachers either for their own school or for a group of partner schools.

Training your own and facilitating the needs of Head Teachers in the local community was the drive (for participating in School Direct). (School co-ordinator, School Direct England)

Interviewer: Does that (looking to recruit good NQTs) play any role in your motivation to take on trainees?

Interviewee: Absolutely, yeah, I think it's definitely a motivating factor (School Direct coordinator, England)

This focus could affect criteria for recruitment through perception of the school's organisational needs or through seeking a match with the school's approach to educating children.

I've sat in a number of School Direct interviews, ... and the first, discussion about each candidate was always orientated around can we see them fitting into this department? (HEI research intensive tutor, England)

Whether they would work well in the department I guess is whether they'd be personable (Head of Mathematics, Secondary School with School Direct, England)

You need someone who is engaged in, has a similar way of thinking about children (Teacher TeachFirst Wales)

To see whether the candidate is going to be suitable for our school or not..., because our pupils are unique (Teacher 1, Co-ordinator of teacher education, Secondary School with School Direct, England)

One positive aspect of this focus on 'training your own' was that schools appeared to be more attentive to recruits' career trajectories beyond ITE. This concern was also apparent in Scotland where there is a stronger link than in England between institutional support for newly qualified teachers and their experience in ITE.

One of our philosophies is grow your own, train your own, keep your own. (Local Authority officer, Scotland)

Despite the public accountability evident in ITE provider league tables, HE tutors in England and Wales expressed less engagement with the subsequent trajectories of beginning teachers and commented that they had insufficient access to the kind of evidence that would make this possible. As one HE tutor in Wales remarked:

I wouldn't have any statistics for... after they've left us (HEI tutor, Wales)

When HEI tutors referred to matching they cited the needs of a community that a particular type of school aimed to serve.

We look for a commitment to being a Catholic teacher in a Catholic school, what that means. So, preparing children for the sacraments, for example, being a faith witness and participating in the liturgical and prayer life of the school; we look for them to have at least a commitment to that. (HE admissions officer, Scotland) 
Any form of matching at point of recruitment raises the question of whether ITE can prepare any recruit for any school: is it feasible to regard ITE as enabling human capital development that is general to all schools? HEI tutors (apart from those serving Catholic schools) and a minority of school co-ordinators claimed that by providing contrasting school experiences they could prepare new teachers for very different schools.

We're making this very clear now, you will go into different schools, while you're here... you're going to be exposed to difference. (HEI tutor, NI)

Unless you can then, at the end, that finished product can go and teach in an inner city school, then we've not done our job. (School co-ordinator at suburban school, School Direct, Secondary School England)

\subsection{Costs, benefits and uncertainty}

Providers in all jurisdictions acknowledged a tension between income for their institution and entry standards. Moreover, interviewees claimed they could judge when the benefits of additional income were more than offset by the costs of recruiting applicants who were less than adequate. However, this tension only became a material factor in recruitment for 'disadvantaged' providers: HEIs with less prestigious reputations and schools facing difficulties in recruiting new teachers

Interviewer: Are you conscious, then, of working with people who've been recruited by others that you're thinking, well, I wouldn't have taken you on?

Interviewee: Absolutely, because we're under massive pressure to recruit and ... we need to get them in and absolutely, there is no doubt that there are some that fit on paper, that are saying the things that you would expect, but is your gut feeling it? No. (HEI teaching intensive tutor, England)

I don't know whether some institutions are driven by the finance side of, because funding is cut in schools and it could be seen as a lucrative income. (Co-ordinator of teacher education, Secondary School with School Direct, England).

I query why we recruit as many people onto teaching courses as we do when we don't need them all. So why don't we just push up the benchmark and just recruit the, bring the best people in? (HE Tutor Wales)

HE and school providers were also mindful of reputational effects for future recruitment and for their standing within the profession.

I think because of our name and the quality that has come from this school, when teachers get a job elsewhere, we want to carry that on. (Co-ordinator of teacher education, Secondary School with School Direct, England)

Despite believing in their capacity to distinguish between marginal candidates, recruiters referred to two main sources of uncertainty: the challenge of balancing different criteria and the predictive power of the indicators they used. Recruiters referred to a wide range of criteria they used to judge applicants: (i) knowledge and understanding as indicated by academic achievements and functional skills; (ii) communication and engagement; (iii) character \& motivation; (iv) life experience; and (v) reflection and ability to learn and adapt. This plurality creates a weighting problem. HE tutors in Wales and Northern Ireland described the scoring systems they were expected to use to address this problem. Most expressed the view that their own professional instincts were more likely to lead to good decisions than the strict application of a scoring system. Interviewees in each jurisdiction and each type of provider aimed to resolve the problem by using multiple threshold criteria (such as degree classification, literacy of applications, skills tests and school experience as a 'helper) to rule out unacceptable applicants and then relying on professional instincts which they found difficult to relate to their espoused criteria.

It's that indefinable again almost, isn't it, did he have that $X$ factor, no, he didn't have that, but even they, I don't think could put into words, but we all knew what we meant, (HEI tutor on recruitment decision taken with head teachers in School Direct provision, England) 
It sounds corny but you get a feel for people, don't you? (Primary Head teacher, School Direct, England)

Really you do only need one question and a bit of a conversation to find out what you are looking for. [Yes] You sort of still have that instinctive, (HEI tutor Wales)

There's still people who are good, but you know the ones that really leap out and you think, yes, you'll make it. (HEI tutor N. Ireland)

HEI tutors in each jurisdiction expressed greater scepticism about the relationship between academic qualifications and the knowledge required for teaching.

The qualifications are really important, (Primary School Head teacher, School Direct, England)

Sometimes, people who are excellent at Maths, who've come with a First from Oxford or Cambridge, it goes back to this whole idea that they've always understood it, sometimes they don't understand those sort of basic principles, or they can't see it in different ways and explain it in different ways. _ (HEI research intensive tutor, England)

They've just understood it from an instrumental point of view to pass their GCSE, to pass their $A^{\prime}$ Level and have done very well, but don't actually understand the underlying principles, then you've got issues really, but I don't think you can actually determine that in an interview (HEI research intensive tutor, England)

Recruiters also stressed applicants' future ability to engage with children and to understand and choose between alternative teaching strategies. As noted earlier, this criterion was largely treated as independent from subject content knowledge and also acknowledged as difficult to predict. As with judgements about subject knowledge, HEI tutors tended to be more cautious about the indicators they could use.

One of the biggest problems with asking candidates about their experience is they've never had experience really as a class teacher. (HEI Research intensive tutor, England)

Nonetheless, most HEI tutors judged aptitude for pedagogy through applicants' interactions with adults during the recruitment process.

(of an oral presentation) It gives the panel, who don't hardly speak at all, an immediate view of someone's preparation skills, understanding of selection of the piece, delivering the piece, communicating, without having any questions thrown at them. (HEI tutor Northern Ireland)

In contrast, School Direct co-ordinators emphasised their observation of how applicants worked with small groups of children during the selection process. Teachers had access to information that was more closely connected with the criterion for judgement, although this might have encouraged greater emphasis on what applicants could do now as opposed to what they could do after ITE.

Schools faced stronger incentives than HEIs to emphasise what they referred to as 'classroom readiness'. These incentives were created by additional costs that discouraged schools from accepting 'adequate' applicants. First, in a traditional route a school can more easily mitigate the effect on children of a struggling recruit (ultimately by telling the provider that the recruit needs to be moved). In these circumstances, teachers spoke of their primary allegiance as lying with the children, whereas HEI tutors referred to their primary allegiance with beginning teachers. One referred to this as a 'moral obligation'. Second, whereas the burden of a struggling recruit in a 'traditional' route is shared between the HEI and the school in a School Direct route the extra workload falls mainly on teachers in that school

(in School Direct) You're placing them in a department for a significantly longer period of time than you would on an all PGCE and that department is taking more responsibility for them, that first thought that's going through their mind is, is this person going to bring shedload of extra workload. _(HEI research intensive tutor, England)

We haven't got time to get involved with organisations that don't send great people through Head teacher, Primary School, School Direct, England) 
Therefore there was an inherent logic in schools being more inclined than HEIs to 'play safe'.

Head Teachers can be more rigorous in terms of their expectations of the degree. We may accept a 2:2 on our PGCE route, but a Head Teacher on a School Direct alliance might be very, very strict that they only want 2:1 and above. (HEI teaching intensive tutor, England)

Traditionally people who've perhaps worked in industry and are coming out and wanting to sort of get straight in there, they've got perhaps a few more years of experience, have got the confidence to be there straight away in the classroom (Head of Department, School Direct, England).

I've interviewed some real quality candidates for salaried routes in particular, but the schools don't want them because they have the person that they want and who is their HLTA (Higher Level Teaching Assistant) as part of the candidates, so they will go for that person who, at times, has been weaker at the interview process. (HEI teaching intensive tutor England)

Regardless of whether the criteria being employed are, in fact, good predictors of subsequent teacher quality, schools tended to emphasise immediate rather than future capability and teachers used the phrase 'classroom readiness' to convey this emphasis. HEI tutors appeared to give more weight to potential for development than readiness to cope with the organisational demands of the classroom.

Some people who are quite, you know they want to show that they are confident because they are the first person. Yes, sometimes confidence is good but sometimes the person holds back is a little bit of everything (HEI tutor, Wales)

We're always looking for potential, we're not looking for a finished article. (HEI research intensive tutor, England)

\subsection{Summary}

The shift towards school leadership in recruitment to ITE in England has occurred in a policy context that has been variously described as 'organisational professionalism', 'performativity' and 'standards driven'. This contrasts with education policy elsewhere in the UK where the idea of occupational professionalism has been reinforced by academic-led policy reviews commissioned by governments in Northern Ireland, Scotland and Wales. Our HEI interviewees in England had maintained an 'occupational professionalism' perspective similar to their colleagues in HEIs elsewhere in the UK. HEI tutors claimed to use similar criteria, similar indicators and similar processes. Decisions about marginal applicants were related to providers' market position rather than professional perspective.

Schools that accept government quality standards for teaching and which closely monitor and evaluate teacher performance should be less concerned than HEI tutors that new teachers might exploit classroom autonomy to the disadvantage of children. However, the School Direct coordinators we interviewed were as emphatic as HEI tutors about the importance of applicants' work ethic and passion for working with children. We did, however, find some indications that HEI tutors were more likely than teachers recruiting for School Direct to believe that knowledge for teaching was complex and that developing this knowledge could be arduous and troublesome. HEI tutors were more likely to refer to looking for signs that applicants had the capacity and appetite for profound learning from the experience of teaching.

However, this apparent difference in epistemological beliefs looked more complex in relation to the trust that recruiters placed in the indicators they were using. HEI tutors and School Direct recruiters used degree classification as an indicator of subject knowledge, but many HEI tutors said they were sceptical of its predictive value (in line with available evidence). Conversely, HEI tutors relied on engagement with adults during the recruitment process as an indicator of engagement with children, whereas School Direct recruiters relied on applicants' engagement with pupils during the recruitment process. Moreover, all recruiters expressed much more confidence in their ability to judge applicants than we might have expected either from their reservations about available indicators or the evidence base on recruitment processes. There were signs of confidence bias in beliefs about the efficacy of professional judgement. 
We also found that the School Direct recruiters we interviewed tended to be looking for an organisational match between applicants and their school: either in terms of 'fitting in' with the school organisation and ethos or sharing the school's perspective on what schooling should be like. Teachers explained this emphasis in relation to their expectations that ITE recruits would progress to teaching jobs either in that school or one of its partner schools. Most of the HEI tutors we interviewed expressed their purpose as preparing recruits for a diverse schooling system. Those HEI tutors who had participated in interviews for School Direct claimed that some applicants were being rejected from one school where they 'did not fit in' when they would have been welcomed as 'strong candidates' at another nearby school.

Finally, and perhaps most critically, schools faced greater costs than HEIs if they accepted a marginal candidate who did not live up to expectations. Therefore, they had more incentive than HEIs to be cautious. Moreover, schools placed more weight on what they perceived as applicants' 'classroom readiness' at point of recruitment and less weight on capacity to improve.

\section{Conclusion}

We examined relationships between the context and recruitment to ITE. Our investigation was prompted by two observations that are now well grounded in evidence from different countries: the quality of teachers dominates the effect of schools on students' achievements and the quality of the teaching force is shaped in part by who is recruited. 'Home international' comparisons between the jurisdictions of the United Kingdom enable a perspective on whether the process of recruitment to ITE might be important for the subsequent quality and character of the teaching force. Policy makers in England have recently shifted the balance of responsibility for recruitment from HEIs to schools. Policy makers in Wales are considering a similar change, but at present their recruitment is firmly in the control of HEIs. Recruitment to ITE in Northern Ireland remains firmly in the control of HEIs whilst policymakers in Scotland remain committed to its partnership of HEIs and local authorities in recruiting to ITE.

To some extent these differences can be seen in comparisons of policy statements and associated flows in numbers and characteristics of recruits to ITE. Our primary purpose was to improve capacity to interpret these data through a deeper understanding of the recruitment processes that HEIs, schools and local authorities were adopting in different policy contexts. We have used our in-depth qualitative data to suggest a way that researchers, policymakers and practitioners could frame the issues they are addressing. First, recruitment practice will reflect recruiters' perceptions of teaching as an occupational profession, organisational profession or craft (and, therefore, their beliefs about adverse selection and their epistemic beliefs about knowledge for teaching). There may be tendencies towards particular forms of bias such as confidence in the efficacy of professional judgement. Second, recruitment practice will be affected by the degree to which recruiters think of ITE as a universal or specific preparation and in particular whether they treat it as preparation for an organisation or a profession. Recruiters' perceptions in relation to points one and two can be understood in terms of how they position themselves in relation to prevailing policy towards ITE. Third, recruitment practice will be affected by the costs and benefits that accrue to the provider (as opposed to the profession).

This way of framing the problem suggests several predictions which are consistent with available evidence about recruitment to ITE in the UK and the evidence we have presented here. First, a shift from HEI-led to School-led recruitment to ITE will strengthen a move towards organisational professionalism as school networks develop distinctive approaches to education. If schools are licenced to lead ITE on the basis of endorsement from inspections and pupil examination results there is a risk that preparation for teaching will become biased towards the needs of 'successful' schools. Second, the ratio of recruits to target for ITE will be lower if responsibility for recruitment is shifted to schools: schools will be cautious in their decisions because they bear a greater share of the risk from applicants who do not fulfil expectations and schools will reject applicants who will not 'fit in' with 
them but who might fit in elsewhere. Third, school leadership of recruitment to ITE is likely to result in greater weight being given to evidence of applicants' engagement with pupils and stronger emphasis on trainees' subsequent employment trajectories.

Policy plays a strong (though not necessarily) determining role in shaping the context for recruitment to ITE and possibilities for improving the teacher workforce through recruitment have become salient for policymakers as the importance of the individual teacher has become more fully recognised. Policies need to be judged not only by prospects for creating positive effects but also in terms of the unwished for problems that any policy change necessarily creates. Policymakers, like HEI tutors and teachers, would do well to recognise how hard it is to 'let the right one in'.

\section{References}

Allen, M. B. (2005). Eight questions on teacher recruitment and retention: What does the research say? Denver, CO: Education Commission of the States.

Allen, R., Belfield, C, Greaves, E., Sharp, C. \& Walker, M. (2014). The Costs and Benefits of Different Initial Teacher Training Routes, IFS Report R100. London: Institute for Fiscal Studies.

Anfara, V. A., Brown, K. M., \& Mangione, T. L. (2002). Qualitative analysis on stage: Making the research process more public. Educational Researcher, 31(7), 28-38. http://dx.doi.org/ 10.3102/0013189X031007028

Applegate, J. H. (1987). Teacher candidate selection. An overview. Journal of Teacher Education, 38(2), 2-6. http://dx.doi.org/10.1177/002248718703800202

Atteberry, A., Loeb, S., \& Wyckoff, J. (2015). Do first impressions matter? Predicting early career teacher effectiveness. AERA Open, 1(4). http://dx.doi.org/10.1177/2332858415607834

Author (2010a). Details removed for peer review

Author (2010b). Details removed for peer review

Author (2015). Details removed for peer review

Ball, S. J. (2003). The teacher's soul and the terrors of performativity. Journal of Education Policy, 18(2), 215-228.

Barton, L., Barrett, E., Whitty, G., Miles, S., \& Furlong, J. (1994). Teacher education and teacher professionalism in England: Some emerging issues. British Journal of Sociology of Education, 15(4), 529543. http://dx.doi.org/10.1080/0142569940150406

BERA (British Educational Research Association) (2011). Ethical guidelines for educational research. Retrieved from https://www.bera.ac.uk/researchers-resources/resources-for-researchers

Brignall, S., \& Modell, S. (2000). An institutional perspective on performance measurement and management in the 'new public sector'. Management Accounting Research, 11(3), 281-306.

Brisard, E., Menter, I., \& Smith, I. (2007). Researching trends in initial teacher education policy and practice in an era of globalization and devolution: A rationale and a methodology for an AngloScottish 'home international'study. Comparative Education, 43(2), 207-229.

Bryk, A., Lee, V. \& Holland. P. (1993). Catholic schools and the common good. Cambridge, MA: Harvard University Press.

Buchanan, J. M., \& Tullock, G. (1962). The calculus of consent: Logical foundations of constitutional democracy. Ann Arbor, MI: University of Michigan Press. 
Buehl, M. M., \& Fives, H. (2016). The role of epistemic cognition in teacher learning and praxis in J. A. Greene, W. A. Sandoval \& I. Bråten (Eds.), Handbook of epistemic cognition (pp. 247-264). London: Routledge.

Bullough, Jr., R. V. (2011). Ethical and moral matters in teaching and teacher education. Teaching and Teacher Education, 27(1), 21-28. http://dx.doi.org/10.1016/j.tate.2010.09.007

Carrington, B. \& Skelton, C. (2003). Re-thinking 'role models': equal opportunities in teacher recruitment in England and Wales. Journal of Education Policy, 18(3), 253-265. http://dx.doi.org/ $10.1080 / 02680930305573$

Carrington, B., Tymms, P., \& Merrell, C. (2008). Role models, school improvement and the 'gender gap' - do men bring out the best in boys and women the best in girls? British Educational Research Journal, 34(3), 315-327. http://dx.doi.org/10.1080/01411920701532202

Casey, C., \& Childs, R. (2007). Teacher education program admission criteria and what beginning teachers need to know to be successful teachers. Canadian Journal of Educational Administration and Policy, 67, 1-24. Retrieved from http://www.eric.ed.gov/PDFS/EJ806982.pdf http://dx.doi.org/

Caskey, M. M., Peterson, K. D., \& Temple, J. B. (2001). Complex admission selection procedures for a graduate preservice teacher education program. Teacher Education Quarterly, 28(4), 7-21. Retrieved from JStor http://www.jstor.org/stable/23478313?seq=1\#page scan tab contents

Chapman, C. (2013). Academy federations, chains, and teaching schools in England: Reflections on leadership, policy, and practice. Journal of School Choice, 7(3), 334-352.

Chartered Institute of Personnel and Development (CIPD) (2014). Labour market outlook spring 2014. London, CIPD.

Clotfelter, C. T., Ladd, H. F., \& Vigdor, J. L. (2006). Teacher-student matching and the assessment of teacher effectiveness. Journal of Human Resources, 41(4), 778-820. http://dx.doi.org/10.3368/jhr.XLI.4.778

Creswell, J. (1998). Qualitative inquiry and research design: Choosing among five traditions. Thousand Oaks, CA: Sage.

Dee, T. S. (2005). A teacher like me: Does race, ethnicity, or gender matter? American Economic Review, 95(2), 158-165. http://dx.doi.org/10.1257/000282805774670446

Dee, T. S. (2007). Teachers and the gender gaps in student achievement. Journal of Human Resources, 42(3), 528-554. http://dx.doi.org/10.3368/jhr.XLII.3.528

Delfgaauw, J. \& Dur, R. (2008). Incentives and workers' motivation in the public sector. The Economic Journal, 118(525), 171-191. http://dx.doi.org/10.1111/j.1468-0297.2007.02108.x

Department for Education (2011). Training our next generation of outstanding teachers. London: Department for Education.

Donaldson, G. (2011). Teaching Scotland's future: A report of the review of teacher education in Scotland. Edinburgh: Scottish Government.

Doyle, W. (2006). Ecological approaches to classroom management. In C. M. Evertson \& C. S. Weinstein (Eds.), Handbook of classroom management (pp. 97-125). Mahwah, NJ: Lawrence Erlbaum.

Edwards, A., Gilroy, G. \& Hartley, D. (2002) Rethinking teacher education: collaborative responses to uncertainty. London: Routledge Farmer.

Eide, E., Goldhaber, D., \& Brewer, D. (2004). The teacher labour market and teacher quality. Oxford Review of Economic Policy, 20(2), 230-244. http://dx.doi.org/10.1093/oxrep/grh013 
Ellis, V., Maguire, M., Trippestad, T. A., Liu, Y., Yang, X., \& Zeichner, K. (2016). Teaching other people's children, elsewhere, for a while: the rhetoric of a travelling educational reform. Journal of Education Policy, 31(1), 60-80. http://dx.doi.org/10.1080/02680939.2015.1066871

Engberg, M. E. (2004). Improving intergroup relations in higher education: A critical examination of the influence of educational interventions on racial bias. Review of Educational Research, 74(4), 473-524. http://dx.doi.org/10.3102/00346543074004473

Evans, L. (2011) The 'shape' of teacher professionalism in England: professional standards, performance management, professional development and the changes proposed in the 2010 White Paper. British Educational Research Journal, 37(5), 851-870.

http://dx.doi.org/10.1080/01411926.2011.607231

Evetts, J. (2009). New professionalism and new public management: Changes, continuities and consequences. Comparative Sociology, 8(2), 247-266. http://dx.doi.org/10.1163/156913309X421655

Freidson, E. (2001). Professionalism: The third logic. Cambridge: Polity.

Furlong, J. (2015). Teaching tomorrow's teachers: options for the future of initial teacher education in Wales. Oxford: University of Oxford Department of Education.

Furlong, J., Hagger, H. Butcher, C. \& Howson, J. (2006) Review of Initial Teacher Training Provision in Wales; A report to the Welsh Assembly Government (the Furlong Report). Oxford: University of Oxford Department of Education.

Georgellis, Y., Iossa, E., \& Tabvuma, V. (2011). Crowding out intrinsic motivation in the public sector. Journal of Public Administration Research and Theory, 21(3), 473-493.

http://dx.doi.org/10.1093/jopart/muq073

Gilroy, P. (1993). Back to the future: The de-professionalisation of initial teacher education in England and Wales. Australian Journal of Teacher Education, 18(2), 5-14.

http://dx.doi.org/10.14221/ajte.1993v18n2.2

Goldhaber, D., Grout, C., \& Huntington-Klein, N. (2014). It's selective, but is it Effective? Exploring the predictive validity of teacher selection tools. CEDR Policy Brief 2014-9. Seattle, Wa.: University of Washington. Retrieved from http://www.cedr.us/papers/working/CEDR\%20Policy\%20Brief\%2020149.pdf

Gonyea, R. M. (2005). Self-reported data in institutional research: Review and recommendations. New directions for institutional research, 127(5), 73-89. http://dx.doi.org/10.1002/ir.156

Gorman, E. H., \& Sandefur, R. L. (2011). “Golden age," quiescence, and revival: How the sociology of professions became the study of knowledge-based work. Work and Occupations, 38(3), 275-302. http://dx.doi.org/10.1177/0730888411417565

Gove, M. (2010). Speech by Michael Gove to the National College annual conference, Birmingham $25^{\text {th }}$ November 2010. London. Department for Education. Retrieved from https://www.gov.uk/government/speeches/michael-gove-to-the-national-college-annual-conferencebirmingham

Guarino, C. M., Santibanez, L., \& Daley, G. A. (2006). Teacher recruitment and retention: A review of the recent empirical literature. Review of Educational Research, 76(2), 173-208.

http://dx.doi.org/10.3102/00346543076002173

Haberman, M. (1995). Selecting "star" teachers for children and youth in urban poverty. Phi Delta Kappan, 76(10), 777-781. Retrieved from http://eric.ed.gov/?id=EJ505022

Heinz, M. (2013). Tomorrow's teachers - selecting the best: An exploration of the quality rationale behind academic and experiential selection criteria for initial teacher education programmes. 
Educational Assessment, Evaluation and Accountability, 25(2), 93-114. http://dx.doi.org/10.1007/s11092013-9162-1

Higher Education Statistics Agency (HESA). (2015). Destinations of leavers from higher education in the United Kingdom for the academic year 2013/2014 HESA SFR 247. Cheltenham, HESA. Retrieved from https://www.hesa.ac.uk/sfr217\#sfr217chart2

Hoyle, E. (1974) Professionality, professionalism and control in teaching. London Education Review, 3(2), 13-19.

Hurworth, R. (2012) Techniques to assist with interviewing. In Arthur, J., Waring, M., Coe, R. \& Hedges, L. (Eds.), Research methods and methodologies in education (pp. 177-185). London: Sage.

Husbands, C. (2015) Teacher supply: why deregulation is not working. Available online at: https://ioelondonblog.wordpress.com/2014/12/01/teacher-supply-why-deregulation-is-not-working/ Last accessed January $5^{\text {th }} 2016$.

Ingersoll, R.M. \& Merrill, E. (2011). The status of teaching as a profession. In J. Ballantine \& J. Spade (Eds.), Schools and Society: A Sociological Approach to Education 4th Ed. (pp. 185-189). CA, Pine Forge: Sage Publications.

Jackson, C. K. (2013). Match quality, worker productivity, and worker mobility: Direct evidence from teachers. Review of Economics and Statistics, 95(4), 1096-1116. http://dx.doi.org/10.1162/REST_a_00339

Jacobowitz, T. (1994). Admission to teacher education programs: Goodlad's sixth postulate. Journal of Teacher Education, 45(1), 46-64. http://dx.doi.org/10.1177/0022487194045001007

Johnson, L. E., \& Reiman, A. J. (2007). Beginning teacher disposition: Examining the moral/ethical domain. Teaching and Teacher Education, 23(5), 676-687._http://dx.doi.org/10.1016/j.tate.2006.12.006

Kane, T.J., Taylor, E.S., Tyler, J.H. \& Wooten, A.L. (2011). Identifying effective classroom practices using student achievement data, Journal of Human Resources, 46(3), 587-613.

http://dx.doi.org/10.3368/jhr.46.3.587

Kay-Cheng, S. \& Wah Kam. H. (1990) Teacher selection research: The Singapore experience, Singapore Journal of Education, 11(1), 29-37. http://dx.doi.org/10.1080/02188799008547711

Knight, J., Lingard, B., \& Bartlett, L. (1994). Reforming teacher education policy under Labor governments in Australia 1983-93. British Journal of Sociology of Education, 15(4), 451-466. Retrieved from jstor http://www.jstor.org/stable/1393115?seq=1\#page_scan_tab_contents

Levin, J., \& Quinn, M. (2003). Missed opportunities: How we keep high-quality teachers out of urban classrooms. New York: The New Teacher Project.

Lewis, G. \& Frank, S. (2002). Who wants to work for the government? Public Administration Review 62(4), 395-404. http://dx.doi.org/10.1111/0033-3352.00193

Lewis, H. (2013). Written statement- response to the review of Initial Teacher Training (ITT) in Wales.

Cardiff, Welsh Government. Retrieved from

http://gov.wales/about/cabinet/cabinetstatements/2013/itt/?lang=en

Matthews, R.C.O. (1991). The economics of professional ethics: Should the professions be more like businesses? The Economic Journal, 101(407), 737-750. http://dx.doi.org/10.2307/2233853

McKinsey (2007) How the world's best performing school systems come out on top. London: McKinsey: Retrieved from (http://mckinseyonsociety.com/downloads/reports/Education/Worlds_School_Systems_Final.pdf

McLaughlin, T. (2003). Teaching as a practice and a community of practice: The limits of commonality and the demands of diversity. Journal of Philosophy of Education 37(2), 339-352.

http://dx.doi.org/10.1111/1467-9752.00330 
Miles, M.B. \& Huberman, A.M. (1994) Qualitative data analysis. $2^{\text {nd }}$ edn. Thousand Oaks, CA: Sage.

Moran, A. (2008). Challenges surrounding widening participation and fair access to initial teacher education: can it be achieved? Journal of Education for Teaching, 34(1), 63-77.

http://dx.doi.org/10.1080/02607470701773481

Musset, P. (2010) Initial teacher education and continuing training policies in comparative perspective: Current practices in OECD countries and a literature review on potential effects, OECD Working Paper No. 48. Paris: OECD Publishing.

National Audit Office (2016). Training New Teachers. London: National Audit Office.

Ost, B. (2009). How do teachers improve? The relative importance of specific and general human capital. Cornell University ILR School Working Paper 11-29-2009. Retrieved from Cornell University, School of Industrial and Labor Relations site: http://digitalcommons.ilr.cornell.edu/workingpapers/125/

Qu, S. Q., \& Dumay, J. (2011). The qualitative research interview. Qualitative Research in Accounting $\mathcal{E}$ Management, 8(3), 238-264. http://dx.doi.org/10.1108/11766091111162070

Pil, F.K. \& Leana, C. (2009). Applying organizational research to public school reform: the effects of teacher human and social capital on student performance. Academy of Management Journal, 52(6), 11011124. http://dx.doi.org/10.5465/AMJ.2009.47084647

Pring, R. \& Pollard, A. (2011). Education for all: Evidence from the past, principles for the future. London: Institute of Education, University of London.

Rice, P. (2015) School Teachers' Review Body Twenty-Fifth Annual Report. Cm 9044. London: Office of Manpower Economics.

Ritchie, J., Spencer, L. \& O'Connor, W. (2003). Carrying out qualitative analysis. In J. Ritchie \& J. Lewis (Eds.), Qualitative research practice: A guide for social science students and researchers, (pp. 219-262). London: Sage.

Roberts, J. \& Dietrich M. (1999). Conceptualising professionalism: Why economics needs sociology. The American Journal of Economics and Sociology, 58(4), 977-998. http://dx.doi.org/10.1111/j.15367150.1999.tb03404.x

Rowan, B. (1994). Comparing teachers' work with work in other occupations: Notes on the professional status of teaching. Educational Researcher, 23(6), 4-17. http://dx.doi.org/ 10.3102/0013189X023006004

Sahlberg, P., Broadfoot, P., Coolahan, J., Furlong, J. \& Kirk, G. (2014). Aspiring to excellence. Final report of the international review panel on the structure of initial teacher education in Northern Ireland. Belfast, Department of Employment and Learning: Northern Ireland.

Scottish Executive Education Department (SEED) (2001) A Teaching Profession for the 21 $1^{\text {st }}$ Century: Agreement Reached Following the McCrone Report. Edinburgh: SEED.

Scottish Funding Council (2015). Intake targets and funded places for the controlled subject of initial teacher education in universities for academic year 2015-16. 24 February 2015. SFC/AN/04/2015. Retrieved from http://www.sfc.ac.uk/web/FILES/Announcements SFCAN042015 Intaketargetsandfundedplacesforth econt/Intake targets and funded places 2015-16.pdf

Schalock, D. (1979). Research on teacher selection, Review of Research in Education, 7(1), 364-417.

Retrieved from jstor http://www.jstor.org/stable/1167212

Sinclair, W., \& Picogna, J. L. (1974). How are education students selected? Clearinghouse, 48(9), 541-543. http://dx.doi.org/10.1080/00098655.1974.11478558 
Slater, H., Davies, N. M., \& Burgess, S. (2012). Do teachers matter? Measuring the variation in teacher effectiveness in England. Oxford Bulletin of Economics and Statistics, 74(5), 629-645.

http://dx.doi.org/10.1111/j.1468-0084.2011.00666.x

Sleeter, C. E. (2001). Preparing teachers for culturally diverse schools research and the overwhelming presence of whiteness. Journal of Teacher Education, 52(2), 94-106. http://dx.doi.org/ $10.1177 / 0022487101052002002$

Smyth, G. (2013). Who are the teachers and who are the learners? Teacher education for culturally responsive pedagogy. In K. Zeichner, \& X. Zhu (Eds.), Preparing teachers for the 21st century (pp. 297308). Berlin: Springer.

Stoddart, T. (1990). Los Angeles Unified School District intern program: Recruiting and preparing teachers for an urban context. Peabody Journal of Education, 67(3), 84-122. Retrieved from jstor http://www.jstor.org/stable/1492802

Stotko, E. M., Ingram, R. \& Beaty-O'Ferrall, M. E. (2007). Promising strategies for attracting and retaining successful urban teachers. Urban Education, 42(1), 37-51. http://dx.doi.org/ $10.1177 / 0042085906293927$

Tabberer, R. (2013). A Review of Initial Teacher Training in Wales. Cardiff: Welsh Government.

Thomson, D., Cummings, E., Ferguson, A.K., Moizumi, E. M., Sher, Y., Wang, X., Broad, K. \& Childs, R. A. (2011). A role for research in initial teacher education admissions: A case study from one Canadian university. Canadian Journal of Educational Administration and Policy, 121, 1-23. Retrieved from http://eric.ed.gov/?id=EJ936701

Uusiautti, S. \& Määttä, K. (2013). Who is a suitable teacher? The over-100-year long history of student selection for teacher training in Finland. International Journal of Sciences, 2(3), 109-118. Retrieved from http://www.ijsciences.com/pub/issue/2013-03/

Villegas, A. M., \& Davis, D. E. (2007). Approaches to diversifying the teaching force: Attending to issues of recruitment, preparation, and retention. Teacher Education Quarterly, 34(4), 137-147. Retrieved from jstor http://www.jstor.org/stable/23479116

Xu, Z., Ozek, U., \& Corritore, M. (2012). Portability of teacher effectiveness across school settings. Working Paper 77. National Center for Analysis of Longitudinal Data in Education Research. Washington: National Center for Analysis of Longitudinal Data in Education Research.

Wise, A. E. (1987). Effective teacher selection: From recruitment to retention. Santa Monica, CA: The Rand Corporation. 
Figure 1 Ratio of actual ITE recruitment to target

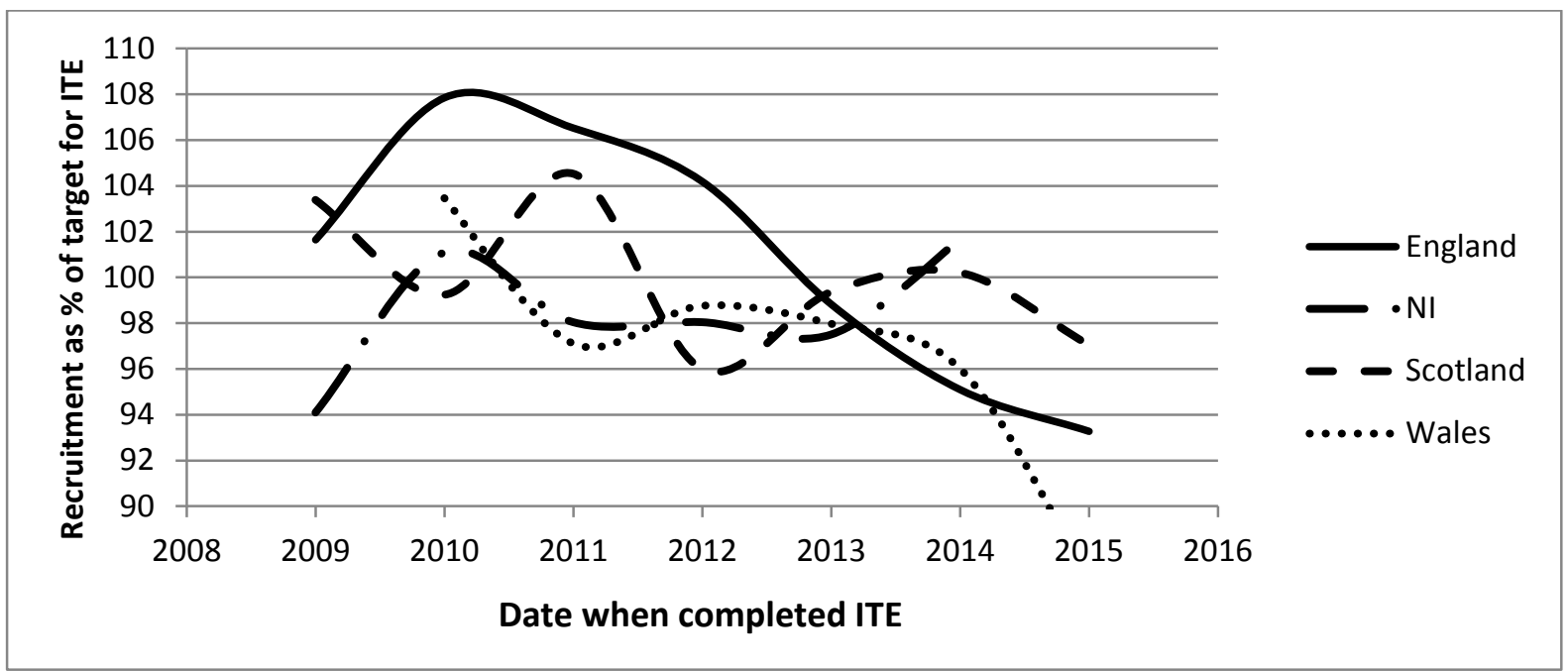

Sources: Higher Education Statistics Agency, National College for Teaching and Learning (2014) Initial Teacher Education Census Data Excel Spreadsheets for 2014/15. London, Department for Education (TSM is the Teacher Supply Model), Scottish Funding Council annual announcements, Higher Education Funding Council for Wales, 
Table 1 Percentage of UK new graduates reporting that they are unemployed 6 months after graduation

\begin{tabular}{|l|c|c|c|c|}
\hline & 2008 & 2009 & 2013 & 2014 \\
\hline Unemployment rate (\%) for graduates & 8.3 & 9.4 & 7.6 & 6.5 \\
\hline
\end{tabular}

Source: Destinations of Leavers of Higher Edition Data provided by the Higher Education Statistics Agency 
Table 2 The distribution of interviewees by jurisdiction and role

\begin{tabular}{|l|c|c|c|c|c|}
\hline & HEI & LA & Sec School & Prim School & $\begin{array}{c}\text { Total for } \\
\text { country }\end{array}$ \\
\hline England & 14 & 0 & 13 & 5 & 32 \\
\hline NI & 6 & & 1 & & 7 \\
\hline Scotland & 4 & 4 & 1 & 1 & 10 \\
\hline Wales & 5 & 1 & 2 & 1 & 9 \\
\hline All countries & 29 & 5 & 17 & 7 & 58 \\
\hline
\end{tabular}

